\title{
The Language Medium Policies: A Study on the Development of Independent Chinese Secondary Schools (ICSS) in Malaysia
}

\author{
Wong Vivien \\ Department of History, Faculty of Arts \& Social Sciences, University of Malaya
}

\begin{abstract}
This paper aims to examine the implementation of the language medium policy and its relative impact on the development of Malaysian Chinese Secondary Schools. The education pathway of the Chinese community in Malaysia is unique, where most of them attain primary education through Chinese-medium schools, but would face a dilemma when deciding on their secondary education pathway. The drastic change of education policy in the early 1960s, coupled with the rising dominance of the National language has marginalised the development of Chinese secondary education and later separated the Chinese secondary schools. This article suggests that the language medium policy is perceived as dysfunctional, as it had failed to result in unity through the implementation of a National language policy, along with strong resistance by the Malaysian Chinese community. This can be seen through the development of the Independent Chinese Secondary Schools (ICSS), which segregated national education into disparate systems. It is also closely linked to the question of access to education opportunities and the Malaysian Chinese preference for the Chinese language as their medium of instruction that contributed to the development and sustainability of the ICSS in Malaysia.
\end{abstract}

Keywords: Language medium policy, medium of instruction, National language, Chinese language, ICSS 


\section{Introduction}

The language medium policy in this paper refers to the medium of instruction adopted in schools in line with Malaysian education policies. The language policies in Malaysia emphasises on the use of the national language, mainly Malay or Bahasa Malaysia as their primary medium of instruction in national schools. Like many other emerging and developed countries, Malaysia has adopted a single language policy, also known as a monolingual policy, similar to the practices of Indonesia, Japan, Britain, Thailand, the United States, Australia, and France (Puteh, 2006). The ethnic composition in Malaysia is dominated by Bumiputeras (consisting of ethnic Malays and the Indigenous People), who are the largest ethnic group constituting 68.8 percent of total population. Respectively, ethnic Chinese and Indians represent 23.2 percent and 7.0 percent, respectively, of the total population 32.0 million as of 2017 (Department of Statistics Malaysia, 2017). The diverse ethnic composition is partly the reason behind the complex education system in Malaysia, where National and National Type (Vernacular) schools adopt different languages as their primary medium of instruction. The integration of vernacular schools happens only at the primary level where four streams of primary schools (Malay, Chinese, Tamil and English) have been integrated into the National educational system. Thereafter, the National secondary and tertiary level uses either Malay or English language as their medium of instruction, while the use of other languages is only available in private schools or institutions (Jeff, 2014). Generally, the National language is the official language of this country, whereas English, Chinese and Tamil are spoken and taught in schools. The introduction of a National language in Malaysia is seen as an essential tool to promote a strong sense of National identity, and, as described by Noss (1967), is a standard language which the written form has primary governmental and official sanctions within a country. The education policy in Malaysia, with its aim of strengthening the status of the National language, has eventually weakened and threatened the development of other community's 
mother tongue languages. This will certainly affect the process of development and nation-building. It also created a degree of ethnic tension in a plural society, whereby the language of the dominant ethnic group is treated as superior, while other languages are deemed inferior (Ali, 1994). Proponents of National languages argue that the speaking of different languages may form a barrier to ethnic integration, while ethnic minorities who defend the use of their mother tongues were often questioned on their loyalty to the country and their readiness to be assimilated into the larger community (Shohamy, 2006). However, language can be a powerful source for unity and separation as stated by Kelman (1971) that, the development of a National language is more disruptive as it may become a major source for internal conflict that may lead to disintegration within a national system. In the context of Malaysia, a Malay-dominated attempt to assimilate the Chinese community to fit into their ideal society has posted threats that would dilute the vernacular identities of other ethnic groups (Ang, 2014) which felt that the importance of their languages had been sidelined. The limitation of the mother tongue education development had provoked heated debates among ethnic groups, especially among the Malaysian Chinese community. It has been argued that national unity can be achieved despite the co-existence of many languages in a country, for instance in Canada where there are English and French; Switzerland where there are French, German, and Italian. It would mean that national unity does not depend solely on a single language policy or culture, but lies in the hearts of its community in a linguistically diverse country. Hence, this article reports a study on the Malaysian language medium policy and its relative impact on the development of Chinese education in Malaysia, by addressing the following questions:

1. How has the National language policy impacted the development of Chinese education in Malaysia?

2. How has the National language medium policy affected the schooling pattern of Malaysian Chinese?

3. What are the significant factors that contribute to the sustainability of ICSS? 


\section{A Brief History of Language Policy in Malaysia}

\section{The Implementation of the National Language}

More than just being the official medium of communication, the national language functions as an identity marker which associates an individual' with being a citizen of a particular nation. The national language described by Fishman (1968), as to plays an important role in fostering national unity in previously Western-colonised countries. Similar argument by Orleans and Orleans (1978) who stated the adoption of the Malay language as the national language instead of English, the colonial language, was seen as an effort to create a symbol of independence from British colonial rule. Most nationalist leaders in Southeast Asia introduced the adoption of a national language to integrate a heterogeneous community. It is also meant to strengthen their countries' national identity, at the same time maintaining their ideologies and political power over other communities (Shohamy, 2006).

In the context of Malaysia, its education policies aimed to achieve its political agenda in unity, national identity, and political stability. Prior to independence, the Malay nationalists were eager to establish a monolingual education system with the use of Malay language as the national language. The adoption of the Malay language, instead of English as the national language was seen as an effort to create a symbol of independence and freedom from the country's previous Western colonial rule. It is stated in the constitution, under Article 152 (a), that, the Malay language shall be the National language, however, "no person shall be prohibited or prevented from using, or from teaching or learning, any other languages" (Federal Constitution, 2010). The status of the Malay language as the national language has been affirmed and other ethnic groups were to accept the development of the national language. As for the Chinese and Tamil languages, they were seen as the "alien" language of the immigrants and minority groups, and therefore, these languages were excluded from being adopted as the national language or the official language (Wong, 1971). 
According to Silcock (1964), the adoption of the Malay language as the national language is the results of Malay political dominance in this country. It would mean that there is a greater chance for a politically dominant ethnic group's language to become the national language because they have the power and authority to make decisions for other groups. This has been described by Gill (2013) as the "top-down" policies in Malaysia, which refer to policy making by people from the top authority, which saw the majority ethnic group having the power to control and influence the language medium policies in this country (Kaplan \& Baldauf, 1997).

Studies have shown that the adoption of a language by the leader of a country is most likely to associate with the benefit of the whole nation in narrowing the ethnic divide rather than ethnicity maintenance. However, a speech ${ }^{1}$ by Tan Cheng Lock argued that "people do not become more civilised by losing contact with their roots. A man's native speech is like his shadow, inseparable from his personality" (Tan, 1988). Further stated by Webb (2004, 235), "the use of a second language as the medium of instruction is not advisable where first language literacy skills have not been meaningfully developed and where the national language has a lower social and economic value than the second language." In Malaysia, primary education is taught by using the mother tongue languages and later most of the students experienced the switching of medium of instruction to the national language in their secondary education, particularly the Chinese. The efforts of strengthening the status of the national language in this country can be seen where it is used as a ticket for entering government civil service; a qualification in the selection of secondary schools and government examinations; scholarships application; requirement in teacher training courses and examinations. The lack of opportunities for the Chinese to develop their mother tongue competences to a higher level and the unequal treatment of their mother tongue language development has resulted in frustration among the Chinese community, as an affront to their cultural identity (Helen, 2013).

\footnotetext{
${ }^{1}$ Speech by Tan Cheng Lock at the Conference of Chinese School Committees and Teachers on 9 November 1952 in the Selangor Chinese Assembly Hall, Kuala Lumpur.
} 


\section{NATIONAL LANGUAGE AS MEDIUM OF INSTRUCTION IN 1950- 1960S}

The language medium policy in Malaysia traces its roots back to the Razak Report of 1956, which highlighted that the ultimate objective of the education policy is to bring together the children of all races under a national education system with the use of the national language as the medium of instruction. The present scenarios in the Malaysian education system are as follow:

a) National \& National Type schools: Primary: use Malay, Mandarin, Tamil, and English ${ }^{2}$ as a medium of instruction; Secondary: use Malay and English as a medium of instruction.

b) Private schools: Primary: use Malay, Mandarin, Tamil, English, and Arabic as a medium of instruction; Secondary: use Malay, Mandarin, English, and Arabic as a medium of instruction.

c) Independent

Chinese Secondary

School (ICSS): $\quad$ Primary and Secondary : use Mandarin as a medium of instruction.

d) Tertiary level

(government/private): use Malay, English, Mandarin, or Arabic as a medium of instruction in universities and colleges.

The language medium policy which contradicts with the interest of the Chinese community has found ethnic Chinese regarding Chinese schools and Chinese education as their "last bastion" in preserving both ethnic and national identity. They believe that education and culture are associated, and function cooperatively, where the culture is nurtured by education and both are seen as equally essential in the nation-building process. The issue seems impossible to resolve since the national identity and the ethnic

\footnotetext{
${ }^{2}$ English-medium schools affected by the language switch from Primary One in 1970.
} 
identity may not be satisfied at the same time. The demands for education among Chinese community were not in sync with the national schools in socialising the young generation. For instance, socialisation in Chinese schools is regarded as a process of transmission of their cultural identity. Whereas society reformation places its emphasis on national schools to reform the pluralistic society to a homogenous one.

Many studies have proven that language is an important mode of communication, especially the mother tongue language which is seen as the most effective in shaping the intellect and character of an individual (Kosonen, 2005 \& Tan, 2007; Rezvan, 2008; Anja, 2013; Tulasiewicz, 2005). Students developed a better understanding of certain subjects like history and geography when these subjects were taught in their first languages in schools (OECD, 2002). Also, language is regarded as a crucial element for ethnic identity maintenance, a symbol of heritage and the soul of an ethnic group, where, as described by Enloe (1970), the "Chinese think of language not so much in terms of the nation's character as in terms of the preservation of their own subnational community." This would mean that as long the Chinese community has the opportunity in developing and preserving the Chinese language, they would regard education as playing an important role in sustaining their mother tongue language. There are several factors that determine the Chinese language survival. Cultural factor is seen as a major contribution to the maintenance of the Chinese language and education in Malaysia.

Since the early nineteenth century, Chinese educational institutions in Malaya were founded by Chinese settlers ${ }^{3}$ with the intention to provide their children an opportunity to learn their mother tongue languages or dialects. The Chinese immigrants could not expect much assistance from the colonial government to provide or to safeguard their interests so they set up their schools through

\footnotetext{
${ }^{3}$ They have come from the Southern part of China's provinces (sheng: 省): Kiangsi (江西省), Hunan (湖南省), Kwangsi (广西 省), Fukien (福建省), Kwangtung (广东 省) and Hainan (海南省). The Chinese community in Malaysia identifies themselves as the descendants of Chinese, or Huayi (华裔) though they are further divided into sub-dialects groups with different dialects (方言) such as Kung Fu, Teochew, Hokkien, Cantonese and Hakka. The medium of instruction for Chinese schools prior to 1910, was in their respective dialects and later Кио-уи (Mandarin) as the medium of instruction. Scholars suggested that the first Chinese school in Malaya was founded in Penang in 1819, known as Wu Fu Shu Yuan.
} 
their own community's effort, which were mostly funded by wealthy Chinese taukehs. By 1938, there were already 996 Chinese primary schools and 36 Chinese secondary schools in Malaya (Tan, \& Teoh, 2015). The early development of these schools was not only to transfer the ethnic cultural identity to the next generation and to nurture their talents, but also to prepare them to serve their nation of adoption. The first Chinese generation had successfully built a solid foundation of Chinese education even prior to the country achieving its independence.

However, the freedom to develop their community's schools had come to an end when the Malayan government reviewed its educational policy, which was aimed at reducing social conflict and improve communication between students from different backgrounds. The enactment of the national language as the sole official language and the main medium of instruction in school have threatened their mother tongue language. Particularly through the Education Act of 1961, the government had gradually eliminated vernacular schools and replace them with national schools (Helen, 2013). This had prohibited the development of other ethnic languages and was found to have not met its intended goals, as it had further discouraged national unity and its goals to achieve education efficacy.

The Malaysian language medium policy prior to independence has emphasised on achieving the ultimate objective as initiated by the Razak Report in 1956, Paragraph 12 “...the ultimate objective of educational policy in this country must be to bring together the children of all races under a national education system in which the national language is the main medium of instruction" (Tay, 2001, 320). It was subsequently adopted by the Rahman Talib Report in 1960. A review of education policy was undertaken to ensure the adoption of the national language as the medium of instruction. The report supported the proposal for a monolingual policy with the national language as the main medium of instruction for national primary and secondary schools. The report has later become the basis for the Education Act of 1961. The Report further emphasised the establishment of a uniform national education system in terms of the curriculum for all schools in Razak Report, Paragraph 119: "Once all schools are working on a common content syllabus, irrespective 
of the language medium of instruction, we consider the country will have taken the most important step towards establishing a national system of education which will satisfy the needs of the people and promote their cultural, social, economic, and political development as a nation". This is where the Razak committee has accepted the Chinese primary school as an integral part of the national educational system with the use of a common curriculum. The Chinese had regarded government education policies as an intention to phase out their mother tongue education since the Barnes Report in $1950^{4}$. The Chinese community is often seen as displaying a strong sense of cultural separateness on the issue of national language and educational policies. As they felt that their language had been manipulated, it created a desire amongst the Chinese to defend their own cultural identity. The Chinese community regarded education as the pathway to access upward mobility, and a means to protect themselves from the insecurity of being the minority in this region and to be prepared to accept the threats to their culture.

The Education Ordinance of 1957 recommended "a national system of education acceptable to the people of the Federation as a whole which will satisfy their needs and promote their cultural, social, economic and political development as a nation, having regard to intention to make Malay the National Language of the country, whilst preserving and sustaining the growth of the language and culture of other communities living in the country." (Section 3 Education Ordinance, 1957). However, the government's main objective was to make Malay the National Language of the country, or the process of "Malayanisation", rather than preserving other ethnic languages. This is followed by the Rahman Talib Report of 1960, which had supported the idea to promote a national consciousness to lift the Malay language as the official language in this country. The committee felt that Chinese secondary schools had discouraged ethnic integration by using a non-official language as the medium of instruction (Suseela, 2016). Therefore, the committee

\footnotetext{
${ }^{4}$ The Barnes Report was formally announced on June 10, 1951, led by L. J. Barnes. The Barnes committee comprised fourteen members with five European officers and nine Malays headed by L.J. Barnes. It marked the first crisis of the Chinese education movement as the response from the Chinese community against the report. The Barnes Report has been regarded as the most controversial educational report in the history of Chinese education which the main objective of this report is was to propose the establishment of national schools with the use of English and Malay as the medium of instruction by abolishing vernacular schools.
} 
recommended the switching of the medium of instruction to the official language stated in the Rahman Talib Report: "For the sake of national unity...to eliminate communal secondary schools for the national system of assisted schools and to ensure that pupils of all races shall attend both National and National-type secondary schools" (Tan, \& Teoh, 2014). This means that there will only be two types of secondary schools under the national education system with the use of the national language as their primary medium of instruction, while other languages will not be part of the national education system. In short, the report proposed that all children of all ethnicities have no other options but to attend national schools, and the existence of Chinese secondary schools shall no longer be necessary.

\section{The SeParation of Chinese Secondary SChools: The DEVELOPMENT OF ICSS IN THE 1960S}

The Chinese community was much disappointed as the previous education reports showed that the government has little intention to safeguard the status and position of Chinese secondary schools. The anxiety persisted following the implementation of the Education Act of 1961, which has evoked fear through the abolishment of the use of Chinese language as the medium of instruction in secondary schools; and the recommended conversion to National-medium secondary school, otherwise, the government will withdraw funding for these schools if they insist. Chinese secondary schools which refuse to conform to the requirements would be categorised as private schools under Section $54(1)^{5}$, and shall bear all operating expenses without government assistance including the cost of recruitment of teachers. The government recognised the importance of financial funding to the survival of Chinese secondary schools and had hoped that they would eventually accept the proposal.

\footnotetext{
${ }^{5}$ All schools must be registered under Section 54 (1), Education Act 1960 as a private/-independent school if they refused the conversion of school. According to the report on registered private/independent secondary schools, there are a total of 248 private/independent secondary schools which comprises 59 Malay medium schools; 126 English medium schools and 57 Chinese medium schools.
} 
However, the issue of providing quality and equal education for all children previously stated in Section 3 of the Education Ordinance, 1957 is nowhere to be seen in the implementation of Education Act in 1961. The government education policy has excluded Chinese secondary schools from the national education system because of the use of a different medium of instruction in these schools. Chinese language and Chinese education are in this case regarded by the government as a hindrance to nation building rather than being acknowledged for their contribution towards nation building. The Education Act of 1961 stated that all secondary schools must convert into a National school or National-Type in order to receive full assistance from the state government, and all Chinese secondary schools ${ }^{6}$ were given a deadline to make their final decision before 1 January 1962. The harsh reality had forced 54 of the 70 existing Chinese secondary schools to conform to the education policy with the use of the national language and English as their medium of instruction but was allowed to continue with the teaching of Chinese language and Literature as separate subjects. Most Chinese secondary schools converted because they could not afford to lose government funding. Despite the bitterness, there were a total of 16 Chinese secondary schools which chose to retain their autonomy and continue to uphold the Chinese language as their medium of instruction (Tan, 2014). These schools became the first batches of ICSS or Du Zhong in Malaysia. Among the reasons behind the resistance of these schools is the fear of losing the "Chinese traits" and the original character of their schools if they were to become among the conforming schools. Today, $\mathrm{ICSS}^{7}$ are private secondary schools with the use of Chinese language/Mandarin as their main medium of instruction. To the Malaysian Chinese community, the development of ICSS is seen as crucial to sustaining

\footnotetext{
${ }^{6}$ SMJK Chung Ling (锤灵中学), Penang accepted to convert as early as in 1955. Foon Yew High School in Johor is the first Chinese secondary school to become ICSS, and this has influenced others Chinese secondary schools to remain as independent schools. The highest conversion rate of Chinese secondary schools happened in the northern part, while Chinese secondary schools from the southern part mostly became ICSS.

${ }^{7}$ Latest record dated in 2017 from the United Chinese School Association Committees of Malaysia, there are a total of 60 ICSS operating today around East and West Malaysia, - with approximately 85,304 . It recorded an increase of 700 students, which 84,604 in 2014, a growth of 0.82 percent from 2003 for 15 consecutive years (UCSCAM, 2017).
} 
the cultural identity and for being an education institution reserved for the young generation.

\section{THE SUSTAINABILITY OF ICSS IN THE 1970S}

The conversion of the majority Chinese secondary schools since the 1960s is seen not just as an important development of Chinese education in the Malaysian history, but it also illustrates the anxiety and dilemma of social mobility versus cultural attachment of the Chinese community. Although the ICSS were successfully established and they continue with the use of Chinese-medium in school but their survival has always been a great concern. The government's education policy and the perception of the Chinese community, either positive or negative, are both seen as crucial elements which determine the future development and survival of ICSS in Malaysia, e.g. the role of language medium policies plays a major role in the perseverance of Chinese language, and it may influence the perception of the parents in Chinese education at the same time. Both are seen as equally crucial in determining the survival and sustainability of ICSS.

As the Malaysian language medium policy continues to focus on the process of strengthening the use of the national language, it culminated in the National Education Policy in 1970. Bahasa Melayu was later renamed as Bahasa Malaysia. All English schools had to transform into national-medium schools and public universities gradually shifted their medium of instruction to the national language by 1983 . Hence, the admission to public universities will only be given to those who took the public examination. This impacted ICSS, leaving them with no choice but to cater to the demands of the national education system by preparing extra classes for students in order to sit for the public examination. Generally, most students in ICSS were expected to undertake internal (Unified Examination) ${ }^{8}$ as

\footnotetext{
${ }^{8}$ The Unified Examination Certificate (UEC) is available in three levels: Vocational Unified Exam (UEC-V), UEC Junior Middle Level (UEC-JML/JUEC), and Senior Middle Level (UEC-SML/SUEL). The first Unified Examination was held on 11- 17 December 1975. The UEC-V and UEC-JML are available in Chinese syllabus and examination, while others subjects including mathematics, biology, chemistry, physics, book-keeping, accounting and commerce are available in both Chinese and English language. The examinations are held in December every year. UEC is certified by Moody International for ISO 9001:2008, which fulfil the criteria of quality management and continuous improvement (Asmah Haji Omar, 2016 \& Gill, S.K. 2013).
} 
well as the optional external examination (government/public). Some ICSS have gone to the extent of conducting two sessions, Chinese-medium session in the morning and Malay-medium session in the afternoon to prepare their students to sit for both examinations (Ang, 2014). In this case, most of the students from ICSS were more likely to have the opportunity of attaining bilingual capability. However, there are some Chinese parents who decided to send their children to study abroad, and this has led to a steady outmigration of some Chinese professionals, most of whom had questioned and worried about their children's future path in Malaysia. According to statistics (The Star, 2015), there are 20 to 30 percent of ICSS graduates who furthered their tertiary education in Taiwan (UEC curriculum was taken from Taiwan since the mid-1970s); 4 percent in the United Kingdom or the United States and other European countries; 1 percent in Japan, France and other non-English medium countries (UCSCAM, 1985). The national education system which discouraged the use of the Chinese-medium may be partly the reason for brain drain in this country. They felt that the implementation of Malay language at the tertiary level is not serving its economic interest and limited social mobility. The result explains they were often felt that they were not given equal opportunities or undervalued.

The faith of the Chinese community is an important determinant in ensuring the continual development and survival of Chinese schools and ICSS. The 1970s was the turning point for the ICSS, where majority Chinese parents who were reluctant to send their children to national schools began to choose the ICSS as their best available option. The development of ICSS largely depends on the Chinese primary schools where their students come from, and therefore a crucial factor which contributes to their survival. ICSS which use the Chinese language as their medium of instruction is known to be more competitive, its good reputation for strict discipline, and for its trilingual education (Chinese, English, and Malay). The ICSS is regarded by the Chinese community as a success story with the overwhelming passion in Chinese education and support from the community which is essential as the transmitter of cultural identity, but also a symbol of strong pride (Collins, 2006; Cushman \& Gungwu, 1988). During this period, one begins to 
witness the steady growth and development of ICSS. Records show that the number of students rose from 15,890 in 1970 , up to 41,356 in 1980. Scholars suggested that the ICSS are able to cater to the needs of the Chinese community since the government-assisted schools ${ }^{9}$ were using Malay-medium as their medium of instruction (Tham, 1979).

The development of ICSS was initiated by the ambitious group of Chinese educationists affiliated with the United Chinese Schoolteacher Association (UCSTA or Jiaozong) and the United Chinese School Committees Association (UCSCA or Dongzong). They are collectively known as Dongjiaozong. They mobilise the support of the community, Chinese guilds and associations, and Chinese political parties as a pressure group to influence the government in moderating education policies. Dongzong acted as head of ICSS in Malaysia by providing a unified curriculum, syllabus, examination and supervise administration. The ICSS internal examination is conducted in the Chinese language organised by Dongzong known as the Unified Examination or The Unified Examination Certificate (UEC) in 1975. They are responsible for the compilation of all ICSS textbooks, curricula, examinations, teacher training, school fees, student enrollment and student development and career. The extraordinarily strong and emotional response from the Chinese community can be seen as they regarded these 60 ICSS in the 1960s for their role in defending the use of their mother tongue education. These Chinese educationists have championed the right of learning mother tongue language and have successfully gained the support of Chinese parents for their role in preserving the community's cultural identity.

The duration of study in ICSS is six years, consisting of three junior middle level and three senior middle levels (3:3). At the latter level, students in ICSS have to sit for a Unified Examination as a requirement for their certificate at the end of their junior Middle 3 and Senior Middle 3, similar to public examination levels. The major reason for the declining popularity of the UEC is the fact that it had failed to receive an endorsement from the Malaysian government,

\footnotetext{
${ }^{9}$ All converted Chinese secondary schools will only have a minimum 180 minutes per week allocated for the teaching in the Chinese language, and minimum 135 minutes per week for the teaching of Chinese literature.
} 
and its graduates are therefore unqualified for admission into all public tertiary institutions since 1975 . This had certainly dented the confidence of parents, when the value of their mother tongue education from ICSS was being disregarded. The support from parents is consistent at the primary level by enrolling their children in Chinese primary schools. However, the refusal of the government to recognise the UEC has compelled many parents to send their children to national-medium or international schools to obtain a state-recognised certificate to secure their children's future career path and instrumental value.

In fact, the survival of ICSS can be rationalised with the rise of China, where the Chinese language ${ }^{10}$ has risen to prominence to become a world language heavily spoken in China, Taiwan, Hong Kong, and Singapore. Besides China and Taiwan, Malaysia is the only country with a comprehensive Chinese education system in place, despite Chinese not being the official language of this country. Chinese education has been recognised as holistic education and it definitely benefits diverse fields and globalisation needs. The Chinese language clearly has a positive impact on Malaysian education development and nation-building. Although the official language in Malaysia is the Malay language but due to the lack of practical status of this language, it still gives prominence to English and Mandarin. This can be the reason to explain why majority Chinese parents hesitate in sending their children to national-medium schools. At the same time, the Chinese language is still lacking its status in Malaysia since it is not part of the official language which failed to achieve protection in the education policy. As China rise in economic power, the demand for the proficiency in the Chinese language will enable young generation to capture job opportunities and strengthen bilateral economic relations between Malaysia and China. The development of ICSS with the use of Chinese-medium is in a strong position to produce Chinese proficient individuals to cater to the demand of manpower and contribute to nation building. This explains why Chinese educationists strive to demand the government to revise their decision on the role of Chinese language as the medium of instruction to be included in the national education

\footnotetext{
${ }^{10}$ Mandarin, today it is one of the world's most spoken languages. Generally spoken and written form of Chinese and also the mother language of most Malaysian.
} 
system. Chinese educationists more ambitious not just in maintaining the Chinese language as the medium of instruction, but also harbour grand vision in establishing a complete Chinese education system in this country. Since the government rejected UEC graduates into public universities, the successful development of ICSS has inspired Chinese educationists to establish New Era College as a Chinese higher learning institution in the1990s.

It was the national-medium which has somehow catapulted the development of ICSS. According to the statistics from National schools in 2002, out of the population of 2,211,971 pupils, the number of ethnic Chinese students is only at 46,470 (2.10 percent), while Indian and other races at 95,180 (4.3 percent) and 59,423 (2.78 percent) respectively. This shows that the participation of nonMalays, especially that of ethnic Chinese students, continue to be low, which then becomes a challenge in forging unity. The adoption of the national-medium forced the ICSS who have opted out of the national system to operate these schools independently in order to cater to the demands of the Chinese community, as most Chinese parents view that ICSS is more culturally and linguistically suited to their community. The major concern of the Malaysian Chinese parents, besides to ensure the preservation of the Chinese language, is to choose a path which guarantees their children upward mobility regardless of the medium of instruction. They felt that the implementation of Malay language at the tertiary level is not serving its economic interest, as it does not contribute to social mobility. In fact, the standard of national-medium secondary schools has been on the decline over time, which prompted a concerned majority of parents to choose ICSS as an alternative pathway for their children (Tham, 1979). For instance, in 1990, the enrolment of the ICSS recorded 54,690; 57,092 in 1996 and 2009 has exceeded 60,000 students; by 2017 it rose to 85,304 (Dong Jiao Zong National Chinese Independent Secondary Schools Working Committee Report in 2000; UCSCAM, 2017). 


\section{DisCUSSION}

Aside from China, Hong Kong and Taiwan, the Chinese community in Malaysia has successfully developed a fairly complete Chinese-medium education system. Unlike other countries, Chinese education in Malaysia is partly built up through the effort of its own communities. While Chinese education is declining in other countries in Indonesia and Singapore, the Chinese community in Malaysia has continued to uphold the spirit of safeguarding the learning of their mother tongue by establishing their own private education system. The segregation of schooling system at the Chinese secondary level can be seen as the failure of the language medium policy, which had intended to abolish other language medium schools which do not conform to the use of National language as the medium of instruction. Every child should be given equal opportunity to learn and be taught in the language of their own choice. If they continue to have opportunities to develop their mother tongue language skills in secondary school, they emerge as fully bilingual (or multilingual) learners. However, children are forced to switch abruptly from learning in their mother tongue to schooling in a second language; their first language acquisition may be attenuated or even lost (UNESCO, 2011). On other issues, the notion that only by using national language or by attending national-medium school will the desired level of national unity be achieved is irrational. The inequality and restriction in learning the language or development of language will create social rejection, e.g. protest and rejection by other ethnic groups. The development of ICSS is the example of ethnic minorities' resistance towards the National language medium policy.

Schooling in a multi-racial country like Malaysia is expected to produce individuals with the bilingual capability to cater to the demand of manpower in the country. The question of unity does not depend solely on the use of a common language. However, unity can be constituted by social bonds or ethnicity [ethnisme], that unity which based upon the differences, including races, religion, culture, etc., without any political unification. The social bond tends to bring about a community of language to some extent constitutes ethnic unity (Hutton, 2012:278). Since the pressure of globalisation is 
driving demand for greater education quality, providing education opportunities rather than uniformity of language should reasonably be the core focus. What really matters is to improve the quality of education regardless of school types, equipping students with the capability of both knowledge and skill as manpower to fill all job positions. Under the provision of Article 152 (National Language), it is clearly stated that Malay is the national language and no one shall be prohibited from using, teaching or learning any other languages. However, the issue of providing equal education opportunity for all children cannot be seen in the implementation of Education Act in 1961, which has explicitly excluded Chinese secondary education from the national education system. It is to acknowledge that this kind of educational diversity is not a major barrier to national unity and is, in fact, able to contribute to nation building.

\section{CONCLUSION}

In conclusion, the Malaysian education system has weaknesses in achieving the desired goal in national unity and encouraging the development of mother tongue education. The language medium policy in Malaysia has failed to achieve the desired national unity, and in fact, it had contributed to ethnic rejection. The current education system had overemphasised on creating unity through the implementation of a common language as the medium of instruction, curriculum and examination system. This study shows that the language medium policy plays a major role in determining the development of other minority languages in Malaysia. It is clear that any change or shift in education policy will determine the future development of the Chinese education. ICSS is created out of the demand for equality in education and the desire to protect the right to use their mother tongue as the medium of instruction in schools. The fact that the Malaysian education policies has discouraged the development of other community's language, which has further developed a segregation of education system and resulted in sustained ethnic separatism. This can be seen as Chinese community in Malaysia has displayed strong resistance against the Nationalmedium policy through the establishment of ICSS. The development 
of ICSS is also closely linked to the concern of the access to mother tongue education opportunities and the development of the complete Chinese education in Malaysia. Parents play key role in selecting the medium of instruction for their children and it reflected on the secondary schooling pattern of the Malaysian Chinese, which not only have been impacted by the language medium policy, particularly on the national language as the medium of instruction but at the same time the demand for better education and opportunities in future job market. The problem of divergence in Malaysia is impossible to resolve if the government's education policy does not provide the opportunity for the development of other community's language. It is unfortunate that preservation of the mother tongue language was regarded as a threat to national aspirations.

\section{REFERENCES}

Ang, Ming C. (2014). Institutions and Social Mobilization: The Chinese Education Movement in Malaysia, 1951-2011, Institute of Southeast Asian Studies.

Anja Langer. (2013). Language of Instruction and Cognitive Development: Case-studies from Malawi, LIT Verlag Munster. Asmah Haji Omar. (2016). Languages in the Malaysian Education System: Monolingual Strands in Multilingual Settings, Routledge.

Alis Puteh. (2006). Language \& Nation Building: A Study of The Language Medium Policy in Malaysia, Petaling Jaya: SIRD. Ali Ashraf. (1994). Ethnic Identity and National Integration, New Delhi: Concept Publishing Company.

Ball, J. (2011). Enhancing Learning of Children from Diverse Language Backgrounds: Mother Tongue-Based Bilingual or Multilingual Education in the Early Years, Paper commissioned for UNESCO, United Nations Educational, Scientific and Cultural Organization.

Cushman, J., Gungwu, W. (1988). Changing Identities of the Southeast Asian Chinese Since World War II: The Ethical Challenge of Biotechnology, Hong Kong University Press, 6174. 
Collins, A. (2006). Chinese Educationist in Malaysia: Defenders of Chinese Identity. Asian Survey, 46 (2), 298-318.

Enloe, Cynthia, H. (1970). Multi-Ethnic Politics: The Case of Malaysia, Research Monograph Series. Berkeley: University of California, Center for South and Southeast Asia Studies.

Fishman, J.A. (1968). Sociolinguistics and the language problems of the developing countries. In J.A. Fishman, C.A. Ferguson \& J.D. Gupta (Eds.), Language problems of developing nations. New York: John Wiley \& Sons, Inc.

Gill, S.K. (2013). Language Policy Challenges in Multi-Ethnic Malaysia, Springer Science \& Business Media.

Helen, Ting. (2013). Language, Identity and Mobility: Perspective of Malaysian Chinese Youth. Malaysian Journal of Chinese Studies, 2 (1), 83-102.

Hutton, C. (2012). Linguistics and the Third Reich: Mother-tongue Fascism, Race and the Science of Language, Routledge.

Ho W. F. (2015, Dec 27). Dong Zong pressured to reform curriculum, The Star.

Jeff, T. (2014). Education Dilemma in Malaysia: Past, Present and Future, Partridge Singapore.

Kaplan, R.B., Baldauf, R.B., Jr. (1997). Language Planning from Practice to Theory. Clevedon: Multilingual Matters.

Kosonen, K. (2005). Education in local languages: Policy and practice in Southeast Asia. First languages first: Communitybased literacy programmes for minority language contexts in Asia. Bangkok: UNESCO Bangkok.

Kelman, H.C. (1971). Language as an aid and barrier to involvement in the national system. In J. Rubin \& B.H. Jernudd (Eds.), Can language be planned? Sociolinguistic theory and practice for developing nations. Honolulu: University Press of Hawaii, 2151.

Noss, R. (1967). Language Policy and Higher Education, Higher Education and Development in Southeast Asia, 3 (2), Paris: UNESCO and International Association of Universities.

Orleans, M., Orleans, R. (1978). National Language Policy and the Education of Ethnic Groups in Malaysia. Humboldt Journal of Social Relations, 6 (1), 39-56. 
OECD. (2002). Understanding the Brain Towards a New Learning Science: Towards a New Learning Science, OECD: Organisation for Economic Co-Operation and Development.

Rezvan Noormohamadi. (2008). Mother Tongue, a necessary step to intellectual development. Journal of Pan-Pacific Association of Applied Linguistics, 12 (2), 25-36.

Silcock, T.H. (1964). Southeast Asian University: A Comparative Account of Some Development Problems, North Carolina, Duke University Press.

Shohamy, E.G. (2006). Language Policy: Hidden Agendas and New Approaches, Routledge.

Suseela M., Rengasamy, N. C. (2016). Policy Discourses in Malaysian Education: A Nation in the Making, Routledge.

Tan, Y.S. (2014). Pendidikan Cina di Malaysia: Sejarah, Politik dan Gerakan Perjuangan, Pulau Pinang: Penerbit Universiti Sains Malaysia.

Tan, Y.S. (2007). Problems and Challenges of Learning through A Second Language: The Case of Teaching of Science and Mathematics in English in the Malaysian Primary Schools, Kajian Malaysia, Vol. XXV, 2, 29-54.

Tay, L.S. (2001). History of Chinese Education in Malaysia (马来 西亚华文教育发展史), Vol. 3, Kuala Lumpur: The United Chinese School Teachers' Association of Malaysia (UCSTAM). Tay, L.S. (2001). History of Chinese Education in Malaysia (马来 西亚华文教育发展史), Vol. 4, Kuala Lumpur: The United Chinese School Teachers' Association of Malaysia (UCSTAM). Tan, Y. S., Teoh, H. See. (2014). The development of Chinese Education in Malaysia, 1952-1975: Political Collaboration Between the Malaysian Chinese Association and the Chinese Educationists, History of Education: Journal of the History of Education Society, 44 (1), 83-100.

Tan, Y.S., Teoh H. See. (2015). The Chinese Language Movement in Malaysia, 1952-1967: Language, Ethnicity and NationBuilding in a Plural Society, Kuala Lumpur: SIRD.

Tan, Y. S. (2014). Pendidikan Cina di Malaysia: Sejarah, Politik dan Gerakan Perjuangan, Pulau Pinang: Penerbit Universiti Sains Malaysia. 
Tan, L. E. (1988). 'Tan Cheng Lock and the Chinese Education Issue in Malaya', Journal of Southeast Asian Studies, 19 (1),4861.

Tulasiewicz, W., Anthony A. (2005). Teaching the Mother Tongue in a Multilingual Europe, New York: Continuum.

The United Chinese School Committees' Association of Malaysia (UCSCAM). (1985). Chinese Secondary Schools today (独中今 昔), UCSCAM.

Tham, S.C. (1979). Issues in Malaysian Education: Past, Present, and Future, Journal of Southeast Asian Studies, 10 (2), 321-350.

United Chinese School Committees Asscociation of Malaysia (UCSCAM). 2017. Preliminary Statistics and Analysis Report on total number of students and the Population in Independent Chinese Secondary Schools in 2017, UCSCAM.

United Chinese School Committees Asscociation of Malaysia (UCSCAM). (2017). Dong Jiao Zong National Chinese Independent Secondary Schools Working Committee Report in 2000, UCSCAM.

Webb, V. (2004). Language Policy in post-apartheid South Africa. In J.W. Tollefson \& A.B.M. Tsui (Eds.), Medium of Instruction Policies, LEA, Mahwah, NJ.

Wong, H.K. (1971). The Development of a National Language in Indonesia and Malaysia. Comparative Education, 7 (2), 73-80. 